Pre-print manuscript of following article with supplementary material.

Tetrahedron 2015, 71 (9), p1419-1424

DOIः 10.1016/j.tet.2015.01.019; http://dx.doi.org/10.1016/j.tet.2015.01.019

Graphical Abstract

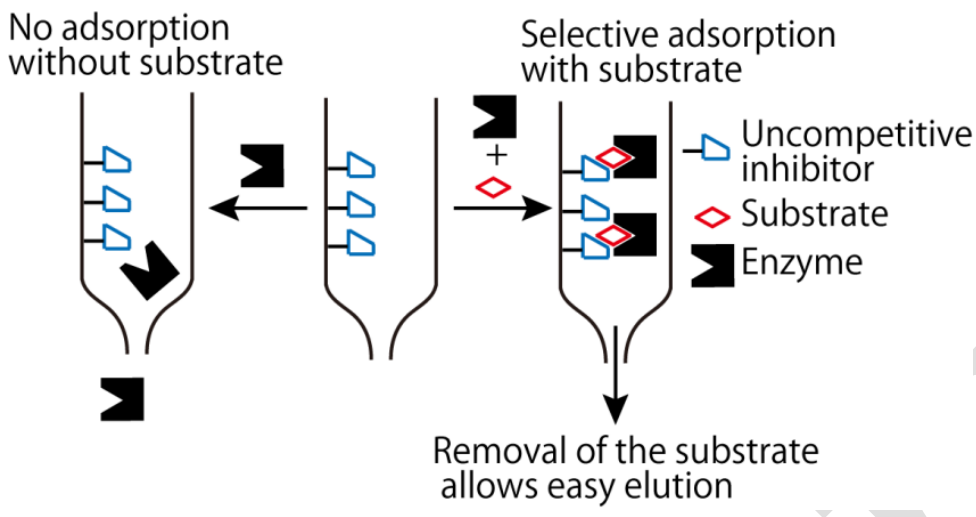




\title{
Selective Purification of Intestinal Maltase Complex by Affinity Chromatography Employing an Uncompetitive Inhibitor as the Ligand
}

Eisuke Kato, ${ }^{*}$ Hiroki Tsuji and Jun Kawabata*

Laboratory of Food Biochemistry, Division of Applied Bioscience, Graduate School of Agriculture, Hokkaido University, Kita-ku, Sapporo, Hokkaido 060-8589, Japan

${ }^{*}$ Corresponding Authors

E. Kato: eikato@chem.agr.hokudai.ac.jp; Tel/Fax:+81-11-706-2496

J. Kawabata: junk@chem.agr.hokudai.ac.jp; Tel/Fax:+81-11-706-2496

\begin{abstract}
Affinity chromatography of specific enzymes is limited by the presence of related enzymes and the limited selectivity of the affinity ligand. We synthesized and investigated the use of an uncompetitive inhibitor as an affinity ligand, to leverage its three-component interactions. Use of the potent $\alpha$-glucosidase uncompetitive inhibitor 2 -aminoresorcinol as the ligand of the affinity gel offered selective purification of maltase-glucoamylase complex from the crude mixture of intestinal $\alpha$-glucosidases.
\end{abstract}

\section{Keywords}

Affinity chromatography, uncompetitive inhibitor, glucosidase inhibitor, intestinal glucosidase, maltase-glucoamylase complex 


\section{Introduction}

Affinity chromatography is a powerful tool for the purification of target molecules. ${ }^{1,2}$ The technique makes use of the specific interactions between pairs of molecules. Expansion of protein expression techniques and development of a method to design and create genetically engineered protein have enabled use of affinity chromatography as an easy and efficient way to purify expressed proteins. Tag sequences, for example the Hisand FLAG-tags, offer an excellent way to distinguish engineered proteins from native proteins. ${ }^{3,4}$ The use of synthetic affinity gels that incorporate a designed ligand offers a systematic approach for purification of tagged proteins..$^{5,6}$

In contrast to engineered proteins, affinity purification of native proteins remains a challenging task. In particular, purification of a specific enzyme from the target organism is often complicated by the presence of related enzymes that catalyze the same reaction but target different substrates. Competitive or mixed-mode inhibitors are frequently selected as the affinity gel ligand for the purification of enzymes..$^{7-10}$ However, these inhibitors often possess inhibitory activity toward multiple related enzymes, making selective adsorption of the target enzyme to the affinity gel difficult when these inhibitors are used as a ligand.11,12 Furthermore, when highly active inhibitors are used, desorption of the target enzyme from the gel requires severe conditions and may co-elute proteins adsorbed by non-specific interactions, hampering purification.

Uncompetitive inhibitors are characteristic inhibitors that bind only to enzyme-substrate complexes. This interaction makes uncompetitive inhibitors more selective and efficient affinity ligand candidates. Because uncompetitive inhibitors bind only to the enzyme-substrate complex, an appropriate substrate is required for them to inhibit enzyme activity. In turn, the substrate can increase the selectivity of the inhibitor. Thus, even if an uncompetitive inhibitor has low selectivity between several enzymes, the presence of the specific substrate is expected to increase the selectivity of the inhibitor.

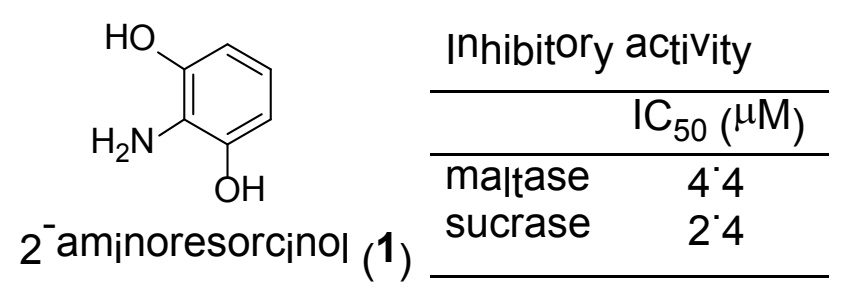

Figure 1. Structure and $\alpha$-glucosidase inhibitory activity of 2 -aminoresorcinol (1).

2-Aminoresorcinol (1) is an uncompetitive a-glucosidase inhibitor that has high 
inhibitory activity toward intestinal glucosidases (Figure 1), ${ }^{13}$ which contain a mixture of two glucosidase complexes, maltase-glucoamylase (MG) and sucrase-isomaltase (SI). Inhibitors of intestinal glucosidases are effective for the treatment of diabetes mellitus and have been extensively studied. ${ }^{14-16}$ Although separation of these complexes has been reported, ${ }^{17,18}$ the steps required are complicated, and most studies have used a mixture of MG and SI, providing rather unclear results concerning the target enzyme of the inhibitors. Thus, a one-step method for purifying these enzymes would facilitate this line of research.

Here, we show for the first time, to the best of our knowledge, the efficacy of an uncompetitive inhibitor as an affinity gel ligand. Using 2-aminoresorcinol (1) as the affinity ligand, we separated intestinal MG from rat intestinal crude enzyme mixture using only simple techniques.

\section{Results and discussion}

\subsection{Synthesis of affinity ligand}

Based on the structure-activity relationship study of (1), 19 an affinity ligand (2) was designed and synthesized (Scheme 1). The 2-Nitroresorcinol derivative (3) was hydrogenated in the presence of di-tert-butyl dicarbonate to yield (4). Initial trial for the amide bond formation reaction between 4 and ethylenediamine linker gave low yield $(\sim 10 \%)$. In addition, the isolation of the resulting product required repeated separations by silica-gel column due to contaminations of unreacted 4 . This was reduced by the protection of para-hydroxyl group with methoxymethyl group which also gave higher yield for the amide bond formation reaction. Thus, para-hydroxyl group of 4 was protected employing equivalent amount of methoxymethyl chloride with diisopropylethylamine as a base at rt. Due to hydrogen bond between carbonyl group, ortho-hydroxyl group has lower reactivity compared to para-hydroxyl group and $\mathbf{5}$ was selectively obtained with slight amount of bis-hydroxyl group protected product, and no ortho-hydroxyl group protected product was obtained. Then, the methyl ester was hydrolyzed to yield (6). A short linker, $N$-Cbz-ethylenediamine, was reacted with (6) in the presence of EDCI and then the Boc group was removed by hydrogen chloride to yield intermediate (8a). Deprotection of the amino group at the end of the linker yielded the desired ligand (2).

An affinity gel (9) was synthesized by the reaction of ligand (2) with NHS-activated sepharose 4 FF (GE Healthcare Co.) under the conditions recommended by the manufacturer (Scheme 1). The amount of residual ligand (2) or released NHS in the coupling solution was monitored by high performance liquid chromatography (HPLC) 
and the ligand concentration or coupling efficiency was calculated. Approximately 19.8 $\mu \mathrm{mol} / \mathrm{mL}$ gel, or $95 \%$ of the activated residue on the gel, was estimated to be modified by the ligand (2).<smiles>COC(=O)c1ccc(O)c([N+](=O)[O-])c1O</smiles>

3<smiles>C1CCCCC1</smiles><smiles>[R6]Oc1ccc(C(=O)OC)c(O)c1NC(=O)O</smiles>
4: $\mathrm{R}=\mathrm{H}$<smiles>COC(=O)Nc1c(OC)ccc(C(=O)O)c1O</smiles>
6

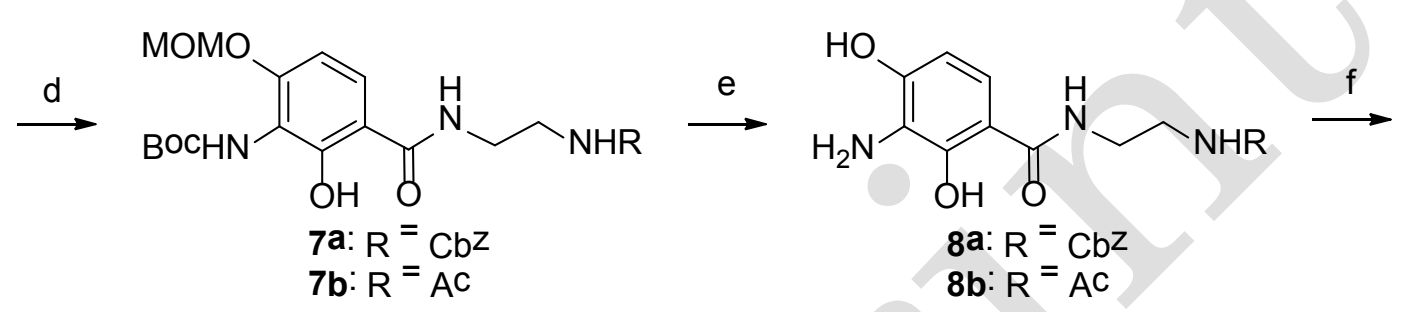<smiles>NCCNC(=O)c1ccc(O)c(N)c1O</smiles><smiles>COCC(=O)NCCNC(=O)c1ccc(O)c(N)c1O</smiles>

Scheme 1. Synthesis of the affinity ligand. (a) $\mathrm{H}_{2}, \mathrm{Pd} / \mathrm{C}$, Boc $2 \mathrm{O}$, THF. (b) MOMCl, DIPEA, DMF. (c) $\mathrm{NaOH}, \mathrm{MeOH}, \mathrm{H}_{2} \mathrm{O}$. (d) for $7 \mathrm{a}: \mathrm{N}$-Cbz-ethylenediamine $\mathrm{HCl}$, EDCI, DIPEA, DMAP, DMF. for 7b: $N$-Acetylethylenediamine, EDCI, DIPEA, DMAP, DMF. (e) $4 \mathrm{M}$ $\mathrm{HCl} /$ dioxane, $0^{\circ} \mathrm{C}$. (f) $\mathrm{H}_{2}, \mathrm{Pd} / \mathrm{C}, \mathrm{MeOH}, 0^{\circ} \mathrm{C}$. (g) NHS-activated sepharose $\mathrm{FF}, 0.2 \mathrm{M}$ $\mathrm{NaHCO}_{3}, 0.5 \mathrm{M} \mathrm{NaCl}$ aq.

\subsection{Uncompetitive mode of inhibition of affinity ligand}

To confirm the uncompetitive mode of inhibition of the derived ligand (2), $N$-acetylated ligand (8b) was prepared and subjected to glucosidase inhibition assay. Variation of ligand (8b) concentration depicted parallel lines in Lineweaver-Burk plot for both maltase and sucrase (Figure 2). The curve is representative for the uncompetitive inhibitor and the result certified that the derived ligand possesses uncompetitive mode of inhibition. The inhibition constant was estimated to be $\mathrm{K}_{\mathrm{i}}=10.6 \mu \mathrm{M}$ for maltase and $\mathrm{K}_{\mathrm{i}}=14.9 \mu \mathrm{M}$ for sucrase from Michaelis-Menten equation (Supplementary Fig. 1). Given the satisfying result of the ligand, we then synthesized the affinity gel (9). 

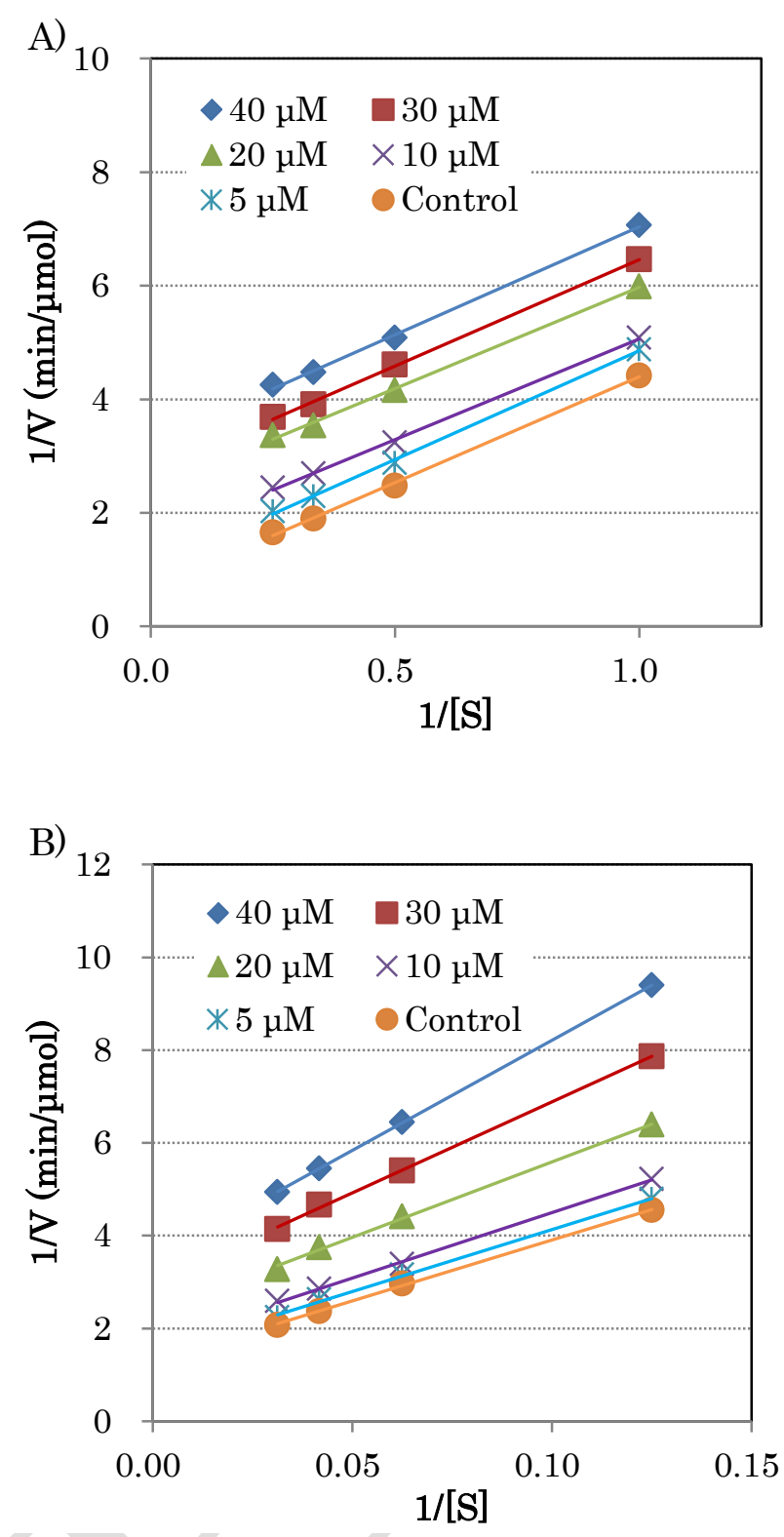

Figure 2. Lineweaver-Burk plot of maltase (A) and sucrase (B) inhibition by the acetylated ligand (8b). Each line indicates varied concentration of $\mathbf{8 b}$.

\subsection{Purification of MG complex}

To test the uncompetitive mode of adsorption, crude enzyme prepared from rat intestinal acetone powder, containing both MG and SI, was passed through the column filled with affinity gel (9) with or without maltose, and the adsorbed maltase was eluted with a sodium chloride solution. As shown in Table 1, the maltase activity of the eluted fractions appeared only when maltose was added to the buffer. This clearly indicated that the ligand was able to adsorb the target enzyme when the substrate was added, 
reflecting the inhibitory mechanism of the uncompetitive inhibitor. Furthermore, the result suggests that the adsorbed enzyme can be eluted simply by removing the substrate, instead of by adding a free inhibitor, changing the $\mathrm{pH}$, or using high concentrations of salt, methods which are often employed.

Table 1. Uncompetitive mode of adsorption of maltase by affinity gel (9)a

\begin{tabular}{ccccc}
\hline & & Adsorbed & \multicolumn{2}{c}{ Maltase activity } \\
\cline { 4 - 5 } Condition & Maltose $^{b}$ & protein & Units & U/mg protein \\
& & $(\mathrm{mg})$ & & 2.85 \\
\hline 1 & + & 0.0284 & 0.08 & - \\
2 & - & 0.0196 & $<0.01$ & 0.08 \\
\hline
\end{tabular}

${ }^{a}$ Crude enzyme (CE) was passed through the affinity gel (9) with or without maltose and then eluted with $1 \mathrm{M}$ sodium chloride. $b$ Following buffer was used during adsorption step. +: $3.5 \mathrm{mM}$ maltose, $5 \mathrm{mM}$ EDTA, 0.1 M phosphate buffer (pH7.0). -: $5 \mathrm{mM}$ EDTA, $0.1 \mathrm{M}$ phosphate buffer (pH7.0).

Next, affinity purification of maltase from the crude enzyme was performed. Crude enzyme was passed through the column filled with gel 9 in the presence of maltose. Maltose was continuously added to the buffer during washing step, and was removed from the buffer at the initial elution step. Then, a sodium chloride containing buffer was used for the secondary elution step. The eluate was fractionated and the maltase /sucrase hydrolyzing activity of each fraction was determined (Figure 3). As expected, the fraction eluted by the maltose-free buffer yielded the highest maltase activity (Figure 2, E2). The maltase activity of the purified fraction was up to 78-fold greater than that of the crude enzyme, whereas the sucrase activity was far lower, indicating that MG was selectively purified (Table 2). The remaining sucrase activity in E2 fraction might be due to the interaction with the Sepharose gel, which is reported to possess a weak interaction with Isomaltase. ${ }^{20}$ Recovery yield of maltase activity in Fr. $\mathrm{E} 2$ was $17 \%$ among the applied crude enzyme. The low recovery yield is probably due to excess enzyme loaded to the column speculated from the result that $53 \%$ of the maltase activity eluted in Fr. W1 and W2. 


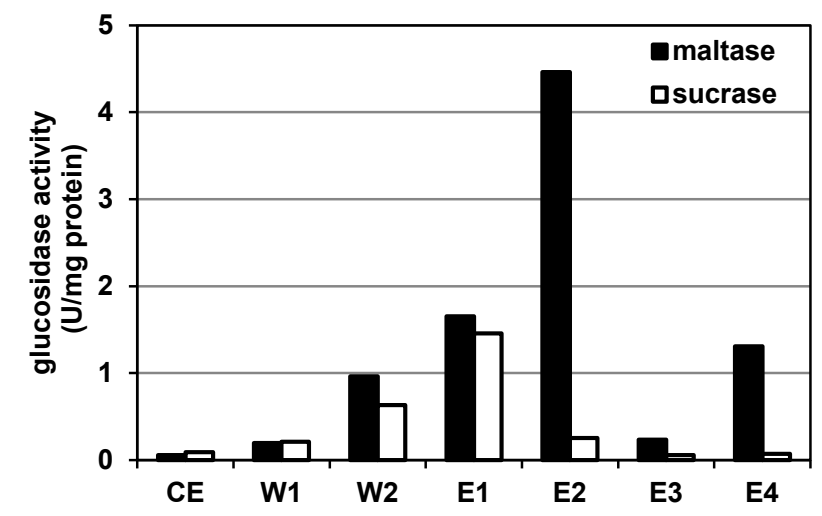

Figure 3. $\alpha$-Glucosidase activity of fractions eluted from the affinity column. Maltase activity and sucrase activity designate the sucrose and maltose hydrolyzing activity. The following buffers were used for the Wash (W) and Elute (E) fractions. W1 and W2: $3.5 \mathrm{mM}$ maltose, $5 \mathrm{mM}$ EDTA, 0.1 M sodium phosphate buffer ( $\mathrm{pH} 7.0$ ); E1 and E2: 5 mM EDTA, 0.1 M sodium phosphate buffer (pH 7.0); E3 and E4: $1 \mathrm{M}$ sodium chloride, 5 mM EDTA, 0.1 M sodium phosphate buffer (pH 7.0).

Table 2. $\alpha$-Glucosidase activity of the crude and purified fractions. ${ }^{a}$

\begin{tabular}{ccccccc}
\hline & \multicolumn{2}{c}{ Maltase } & \multicolumn{2}{c}{ Sucrase } & \multicolumn{2}{c}{ Fold } \\
\cline { 2 - 7 } Fr. & Units & $\begin{array}{c}\text { U/mg } \\
\text { protein }\end{array}$ & Units & $\begin{array}{c}\text { U/mg } \\
\text { protein }\end{array}$ & Maltase & Sucrase \\
\hline CE & 0.573 & 0.057 & 0.917 & 0.091 & 1 & 1 \\
E2 & 0.100 & 4.460 & 0.006 & 0.254 & 78 & 3 \\
\hline
\end{tabular}

aRepresentative value of three independent experiments.

To confirm the obtained enzyme, fraction E2 was analyzed by native-PAGE, SDS-PAGE, and western blotting (Figure 4). Native-PAGE analysis yielded a single band (Figure 4A), which showed maltase activity (data not shown). SDS-PAGE analysis of the fraction confirmed bands at molecular weights of 130 and $240 \mathrm{kDa}$, and another two bands above $250 \mathrm{kDa}$ (Figure 4B). The MG complex is reported to consist of five fragments with molecular weights of 134, 245, 350, 410, and $480 \mathrm{kDa}$, consistent with the current analysis. ${ }^{21,17}$ Western blotting analysis using polyclonal anti-MG antibody showed that all four bands originated from MG (Figure 4C). Thus, all of the purification analyses showed that the purified fraction contained MG as the major component, and that MG was successfully purified using affinity gel (9). 
A)

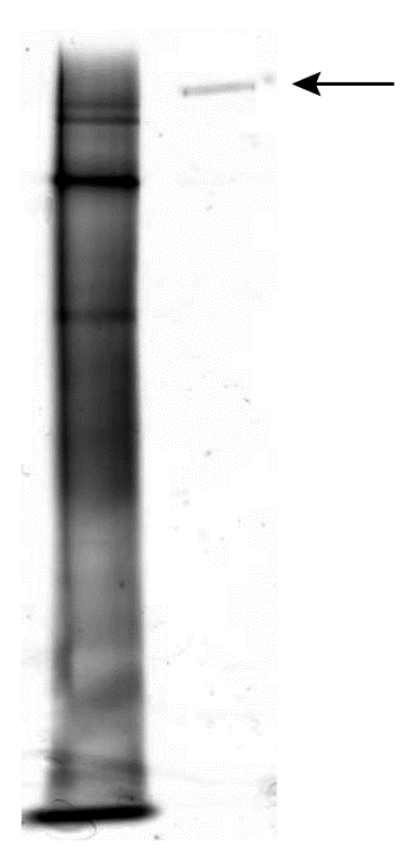

CE E2
B)

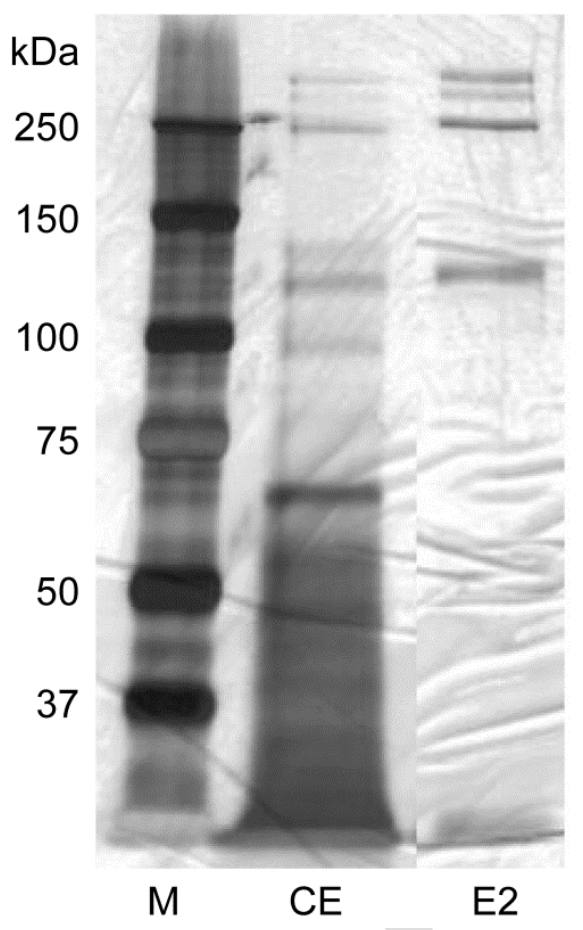

C)

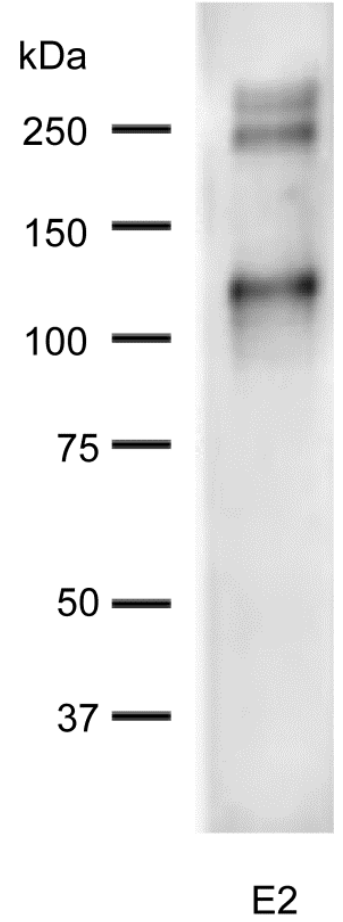

Figure 4. Analysis of the E2 fraction. M: Marker protein, CE: Crude enzyme, E2: E2 fraction. A) Native-PAGE analysis, silver stain. B) SDS-PAGE analysis, silver stain. C) Western blotting analysis with polyclonal anti-maltase-glucoamylase antibody (Santa Cruz Biotechnology, Inc.).

\section{Conclusion}

In conclusion, we employed an uncompetitive a-glucosidase inhibitor (1) as a tool for affinity purification of $M G$ from crude enzyme extract. The unique characteristics of the uncompetitive inhibitor allowed the substrate to act as an additional factor to increase the selectivity of the affinity chromatography, and simultaneously provided a simple and efficient elution procedure. The adsorption and elution steps are the two most important steps in affinity chromatography, and we consider the use of an uncompetitive inhibitor as one of an efficient method for enzyme purification.

\section{Experimental methods}

\subsection{General}

Intestinal acetone powder from rat was purchased from Sigma-Aldrich Co. All other commercially available chemicals were purchased from Wako Pure Chem. Ind. Ltd. and used without further purification. Structures of the synthetic compounds were determined by NMR and Mass 
spectrometry. Bruker AMX500 or Jeol JNM-EX 270 was used to obtain NMR spectrum and either tetramethylsilane (TMS) or residual solvent peak was used as an internal standard $\left({ }^{1} \mathrm{H}\right.$ NMR: TMS 0.00 ppm for $\mathrm{CDCl}_{3}, \mathrm{CD}_{3} \mathrm{OD} 3.30$ ppm, DMSO- $d_{6} 2.49$ ppm; ${ }^{13} \mathrm{C}$ NMR: $\mathrm{CDCl}_{3} 77.0$ ppm, $\mathrm{CD}_{3} \mathrm{OD}$ $49.0 \mathrm{ppm}, \mathrm{DMSO}-d_{6} 39.5 \mathrm{ppm}$ ). Jeol JMS-T100GCV (FD-MS) or Waters LCT Premier (ESI-MS) was used to obtain mass spectrum. IR was measured by FT/IR-4100ST (JASCO Co.). Melting points are measured by MP-S3 (Yanaco New Science Inc.). Absorbance was measured by Synergy ${ }^{\mathrm{TM}} \mathrm{MX}$ (Bio-tech Instruments Inc.) microplate reader.

\subsection{Synthesis}

\section{Methyl 3-(tert-butoxycarbonylamino)-2,4-dihydroxybenzoate (4).}

Compound 3 (220 mg, $1.03 \mathrm{mmol}$ ) was dissolved in THF (10 mL) and Pd-C (50 mg) was added. To this mixture, $\mathrm{Boc}_{2} \mathrm{O}$ (338 $\mathrm{mg}, 1.55 \mathrm{mmol}$ ) was added and reacted for one day under hydrogen atmosphere. The reaction mixture was passed through the celite pad and evaporated. The residue was purified by silica-gel column chromatography (hexane/ethyl acetate $=2 / 1)$ to give $4(136 \mathrm{mg}, 47 \%)$ as the yellow solid.

HR-FD-MS (positive): [M]+ Found $\mathrm{m} / z$ 283.10774, $\mathrm{C}_{13} \mathrm{H}_{17} \mathrm{O}_{6} \mathrm{~N}$ requires $\mathrm{m} / \mathrm{z} 283.10559$; ${ }^{1} \mathrm{H}-\mathrm{NMR}\left(270 \mathrm{MHz}, \mathrm{CDCl}_{3}, \mathrm{rt}\right): 11.54(1 \mathrm{H}, \mathrm{s}), 10.59(1 \mathrm{H}, \mathrm{br}$ s), $7.52(1 \mathrm{H}, \mathrm{d}, J=8.9$ $\mathrm{Hz}), 7.08(1 \mathrm{H}, \mathrm{br} \mathrm{s}) 6.51(1 \mathrm{H}, \mathrm{d}, J=8.9 \mathrm{~Hz}), 3.92(3 \mathrm{H}, \mathrm{s}), 1.54(9 \mathrm{H}, \mathrm{s}) \mathrm{ppm} ;{ }^{13} \mathrm{C}-\mathrm{NMR}(67.8$ $\left.\mathrm{MHz}_{2} \mathrm{CDCl}_{3}, \mathrm{rt}\right): 171.0,156.3,154.1,153.5,126.4,113.9,111.2,104.4,83.1,52.1,28.1$ ppm; IR (neat): 3410, 2980, 1670, 1599, 1534, 1440, 1257, 1158, $1064 \mathrm{~cm}^{-1}$; mp: $180-200^{\circ} \mathrm{C}$ (decomposition).

\section{Methyl 3-(tert-butoxycarbonylamino)-2-hydroxy-4-(methoxymethoxy)benzoate (5).}

Compound 4 (231 mg, $0.815 \mathrm{mmol})$ was dissolved in DMF (10 mL) and diisopropylethylamine $(0.421 \mathrm{~mL}, 2.44 \mathrm{mmol})$ was added. To this mixture, methoxymethyl chloride $(0.067 \mathrm{~mL}, 0.896 \mathrm{mmol})$ was added and reacted for 2.5 hours under argon atmosphere. The reaction mixture was diluted with water and extracted by ethyl acetate. The organic layer was washed with brine, dried over sodium sulfate and evaporated. The residue was purified by silica-gel column chromatography (hexane/ethyl acetate $=3 / 1)$ to give $\mathbf{5}(198 \mathrm{mg}, 74 \%)$ as the yellowish solid.

HR-FD-MS (positive): [M]+ Found $\mathrm{m} / z$ 327.12895, $\mathrm{C}_{15} \mathrm{H}_{21} \mathrm{O}_{7} \mathrm{~N}$ requires $\mathrm{m} / \mathrm{z} 327.13180$; ${ }^{1} \mathrm{H}-\mathrm{NMR}\left(270 \mathrm{MHz}, \mathrm{CDCl}_{3}, \mathrm{rt}\right): 11.15(1 \mathrm{H}, \mathrm{s}, \mathrm{OH}), 7.69(1 \mathrm{H}, \mathrm{d}, J=8.9 \mathrm{~Hz}), 6.70(1 \mathrm{H}, \mathrm{d}, J$ $=8.9 \mathrm{~Hz}), 5.88(1 \mathrm{H}, \mathrm{br} \mathrm{s}), 5.25(2 \mathrm{H}, \mathrm{s}), 3.92(3 \mathrm{H}, \mathrm{s}), 3.50(3 \mathrm{H}, \mathrm{s}), 1.50(9 \mathrm{H}, \mathrm{s}) \mathrm{ppm}$; ${ }^{13} \mathrm{C}-\mathrm{NMR}\left(67.8 \mathrm{MHz}, \mathrm{CDCl}_{3}, \mathrm{rt}\right): 170.3,158.1,158.0,153.7,128.6,114.7,106.9,105.8$, 94.5, 79.8, 56.2, 51.9, 28.0 ppm; IR (neat): 3370, 2979, 1717, 1672, 1506, 1439, 1337, $1271,1153,1048 \mathrm{~cm}^{-1} ; \mathrm{mp}: 142-144^{\circ} \mathrm{C}$. 
3-(tert-butoxycarbonylamino)-2-hydroxy-4-(methoxymethoxy)benzoic acid (6).

Compound 5 (207 mg, $0.632 \mathrm{mmol})$ was dissolved in methanol $(6 \mathrm{~mL})$ and water $(2 \mathrm{~mL})$ was added. To this mixture, aq. solution of $2 \mathrm{M}$ sodium hydroxide $(20 \mathrm{~mL})$ was added and reacted for one day under argon atmosphere. The reaction mixture was acidified by $1 \mathrm{M}$ hydrochloric acid, diluted with water and extracted by ethyl acetate. The organic layer was washed with brine, dried over sodium sulfate and evaporated to give 6 (119 $\mathrm{mg}, 60 \%)$ as the orange oil.

HR-FD-MS (positive): [M]+ Found $\mathrm{m} / \mathrm{z} 313.11783, \mathrm{C}_{14} \mathrm{H}_{19} \mathrm{O}_{7} \mathrm{~N}$ requires $\mathrm{m} / \mathrm{z} 313.11615$; ${ }^{1} \mathrm{H}-\mathrm{NMR}\left(270 \mathrm{MHz}, \mathrm{CDCl}_{3}, \mathrm{rt}\right): 7.80(1 \mathrm{H}, \mathrm{d}, J=8.9 \mathrm{~Hz}), 6.75(1 \mathrm{H}, \mathrm{d}, J=8.9 \mathrm{~Hz}), 6.50(1 \mathrm{H}$,

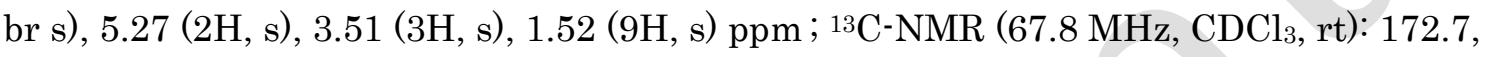
158.20, 158.17, 157.96, 129.8, 114.2, 107.0, 105.6, 94.4, 81.0, 56.2, 27.9 ppm; IR (neat): $3293,2980,1672,1506,1267,1136,1050 \mathrm{~cm}^{-1}$.

\section{$N$-(2-(benzyloxycarbonylamino)ethyl)-}

\section{3-(tert-butoxycarbonylamino)-2-hydroxy-4-(methoxymethoxy)benzamide (7a).}

Compound 6 (223.0 mg, $0.712 \mathrm{mmol})$ was dissolved in DMF (12 mL) and diisopropylethylamine $(0.184 \mathrm{~mL}, 1.424 \mathrm{mmol}) 、$ EDCI (136.5 mg, $0.712 \mathrm{mmol})$, DMAP (cat.) were added. To this mixture, $N$-Cbz-ethylenediamine $\mathrm{HCl}$ (213.5 mg, $0.926 \mathrm{mmol}$ ) was added and reacted for one day under argon atmosphere. The reaction mixture diluted with water and extracted by ethyl acetate. The organic layer was washed with brine, dried over sodium sulfate and evaporated. The residue was purified by silica-gel column chromatography (chloroform/methanol $=20 / 1)$ to give $7(170.0 \mathrm{mg}, 49 \%)$ as the slightly yellow oil.

HR-FD-MS (positive): [M]+ Found $m / z$ 489.21033, $\mathrm{C}_{24} \mathrm{H}_{31} \mathrm{O}_{8} \mathrm{~N}_{3}$ requires $m / z$ 489.21111; ${ }^{1} \mathrm{H}-\mathrm{NMR}\left(270 \mathrm{MHz} \mathrm{CDCl}_{3}, \mathrm{rt}\right): 12.00(1 \mathrm{H}, \mathrm{s}, \mathrm{OH}), 8.11(1 \mathrm{H}, \mathrm{br}, \mathrm{NH}), 7.62(1 \mathrm{H}, \mathrm{d}, J=8.9$ $\mathrm{Hz}), 7.36-7.28(5 \mathrm{H}, \mathrm{m}), 6.70(1 \mathrm{H}, \mathrm{d}, J=8.9 \mathrm{~Hz}), 6.50(1 \mathrm{H}, \mathrm{br} \mathrm{s}, \mathrm{NH}), 5.45(1 \mathrm{H}, \mathrm{br} \mathrm{s}, \mathrm{NH})$, $5.24(2 \mathrm{H}, \mathrm{s}), 5.11(2 \mathrm{H}, \mathrm{s}), 3.55(2 \mathrm{H}, \mathrm{br} \mathrm{t}, J=6.0 \mathrm{~Hz}), 3.51(3 \mathrm{H}, \mathrm{s}), 3.44(2 \mathrm{H}, \mathrm{br} \mathrm{t}, J=6.0 \mathrm{~Hz})$, $1.53(9 \mathrm{H}, \mathrm{s})$; ${ }^{13} \mathrm{C}-\mathrm{NMR}\left(67.8 \mathrm{MHz}, \mathrm{CDCl}_{3}, \mathrm{rt}\right): 169.3,157.3,155.5,155.0,154.9,136.5$, 128.3, 127.9 (2C), 126.0, 115.0, 111.0, 105.3, 94.5, 80.9, 66.4, 56.2, 40.7, 40.1, 28.0 ppm; IR (neat): $3332,2978,1708,1499,1366,1272,1160,1050 \mathrm{~cm}^{-1}$.

\section{3-amino- $N$-(2-benzyloxycarbonylaminoethyl)-2,4-dihydroxybenzamide (8a).}

Compound 7 (127.9 mg, $0.262 \mathrm{mmol}$ ) was dissolved in $4 \mathrm{M}$ hydrogenchloride/1,4-dioxane solution $(5 \mathrm{~mL})$ and reacted for 2 hours at $0^{\circ} \mathrm{C}$ under argon atmosphere. The reaction mixture was evaporated and the residue was purified by silica-gel column 
chromatography (chloroform/methanol $=10 / 1)$ to give $8(53.7 \mathrm{mg}, 60 \%)$ as the slightly yellow oil.

HR-FD-MS (positive): [M] ${ }^{+}$Found $m / z$ 345.13056, $\mathrm{C}_{17} \mathrm{H}_{19} \mathrm{~N}_{3} \mathrm{O}_{5}$ requires $\mathrm{m} / \mathrm{z} 345.13247$; ${ }^{1} \mathrm{H}-\mathrm{NMR}\left(270 \mathrm{MHz}, \mathrm{CD}_{3} \mathrm{OD}, \mathrm{rt}\right): 7.63(1 \mathrm{H}, \mathrm{d}, J=8.9 \mathrm{~Hz}), 7.31-7.26(5 \mathrm{H}, \mathrm{m}), 6.52(1 \mathrm{H}, \mathrm{d}, J$ $=8.9 \mathrm{~Hz}), 5.04(2 \mathrm{H}, \mathrm{s}), 3.47(2 \mathrm{H}, \mathrm{t}, J=5.8 \mathrm{~Hz}), 3.34(2 \mathrm{H}, \mathrm{t}, J=5.8 \mathrm{~Hz}) ;{ }^{13} \mathrm{C}-\mathrm{NMR}(67.8$ $\left.\mathrm{MHz}, \mathrm{CD}_{3} \mathrm{OD}, \mathrm{rt}\right):$ 171.8, 159.4, 158.0, 156.9, 138.4, 129.58, 129.52, 129.0, 128.8, 108.4, 107.5, 107.3, 67.4, 41.1, 40.6 ppm; IR (neat): 3291, 2941, 1654, 1603, 1557, 1282, 1100 $\mathrm{cm}^{-1}$.

\section{3-amino- $N$-(2-aminoethyl)-2,4-dihydroxybenzamide (2).}

Compound 8 (53.7 mg, $0.157 \mathrm{mmol})$ was dissolved in methanol $(3.5 \mathrm{~mL})$ and $\mathrm{Pd}-\mathrm{C}(25$ $\mathrm{mg}$ ) was added. The mixture was reacted for $30 \mathrm{~min}$ at $0^{\circ} \mathrm{C}$ under argon atmosphere. The reaction mixture was passed through the celite pad to give $2(27.9 \mathrm{mg}, 85 \%)$ as the slightly brown oil.

HR-FD-MS (positive): [M]+ Found $m / z$ 211.09340, $\mathrm{C}_{9} \mathrm{H}_{13} \mathrm{O}_{3} \mathrm{~N}_{3}$ requires $\mathrm{m} / z$ 211.09569; ${ }^{1} \mathrm{H}-\mathrm{NMR}\left(270 \mathrm{MHz}, \mathrm{CD}_{3} \mathrm{OD}, \mathrm{rt}\right): 7.10(1 \mathrm{H}, \mathrm{d}, J=8.9 \mathrm{~Hz}), 6.35(1 \mathrm{H}, \mathrm{d}, J=8.9 \mathrm{~Hz}), 3.63(2 \mathrm{H}$, t, $J=5.6 \mathrm{~Hz}), 3.14(2 \mathrm{H}, \mathrm{t}, J=5.6 \mathrm{~Hz}) ;{ }^{13} \mathrm{C}-\mathrm{NMR}\left(67.8 \mathrm{MHz}, \mathrm{CD}_{3} \mathrm{OD}, \mathrm{rt}\right): 173.8,152.6$, 151.2, 123.5, 118.7, 107.7, 107.5, 41.2, 38.1 ppm; IR (neat): 3257, 3050, 1638, 1558, 1288, $1161,1019 \mathrm{~cm}^{-1}$.

\section{$N$-(2-acetamidoethyl)-}

3-(tert-butoxycarbonylamino)-2-hydroxy-4-(methoxymethoxy)benzamide (7b).

Compound $6 \quad(31.5 \mathrm{mg}, 0.10 \mathrm{mmol})$ was dissolved in DMF $(1.0 \mathrm{~mL})$ and diisopropylethylamine $(50 \mu \mathrm{L}, 0.294 \mathrm{mmol})$, HOBt $(15.1 \mathrm{mg}, 0.123 \mathrm{mmol})$ and EDCI (31.6 mg, $0.165 \mathrm{mmol}$ ) was added. To this mixture, $N$-acetylethylenediamine $(17.1 \mathrm{mg}$, $0.167 \mathrm{mmol})$ dissolved in DMF $(0.5 \mathrm{~mL})$ was added and stirred for $16 \mathrm{hrs}$ at $40^{\circ} \mathrm{C}$ under argon atmosphere. The reaction mixture was diluted with $1 \mathrm{M}$ hydrochloric acid and extracted by ethyl acetate. The organic layer was washed with sat. aq. sodium hydrogen carbonate, brine, dried over sodium sulfate and evaporated to give $7 \mathrm{~b}(19.1 \mathrm{mg}, 48 \%)$ as the slightly yellow oil.

HR-FD-MS (positive): [M] ${ }^{+}$Found $m / z$ 397.18437, $\mathrm{C}_{18} \mathrm{H}_{27} \mathrm{O}_{7} \mathrm{~N}_{3}{ }^{+}$requires $\mathrm{m} / z$ 397.18490; ${ }^{1} \mathrm{H}-\mathrm{NMR}\left(270 \mathrm{MHz}, \mathrm{DMSO}-d_{6}, \mathrm{rt}\right): 13.25(1 \mathrm{H}, \mathrm{s}, \mathrm{OH}), 8.80(1 \mathrm{H}, \mathrm{t}, J=5.1 \mathrm{~Hz}, \mathrm{NH}), 8.00$ $(1 \mathrm{H}, \mathrm{t}, J=5.1 \mathrm{~Hz}, \mathrm{NH}), 7.85(1 \mathrm{H}, \mathrm{s}, \mathrm{NH}), 7.68(1 \mathrm{H}, \mathrm{d}, J=9.1 \mathrm{~Hz}), 6.62(1 \mathrm{H}, \mathrm{d}, J=9.1 \mathrm{~Hz})$, $5.21(2 \mathrm{H}, \mathrm{s}), 3.37(3 \mathrm{H}, \mathrm{s}), 3.36-3.28(2 \mathrm{H}, \mathrm{m}), 3.20(2 \mathrm{H}, \mathrm{dt}, \mathrm{J}=5.1,5.8 \mathrm{~Hz}), 1.79(3 \mathrm{H}, \mathrm{s})$, $1.39(9 \mathrm{H}, \mathrm{s}) \mathrm{ppm} ;{ }^{13} \mathrm{C}-\mathrm{NMR}(67.5 \mathrm{MHz}$, DMSO- $d 6, \mathrm{rt}): 170.0,169.8,159.1,157.2,154.0$, 125.8, 115.5, 108.8, 104.8, 93.9, 78.0, 55.7, 38.9, 38.0, 28.0, 22.5 ppm; IR (neat): 3320, 
$2975,2930,1700,1641,1595,1498,1457,1366,1274,1159,1048 \mathrm{~cm}^{-1}$.

\section{$N$-(2-acetamidoethyl)-3-amino-2,4-dihydroxybenzamide (8b).}

Compound $7 \mathrm{~b}(6.2 \mathrm{mg}, 15.6 \mu \mathrm{mol})$ was dissolved in $1.25 \mathrm{M} \mathrm{HCl} / \mathrm{methanol}(0.5 \mathrm{~mL})$ and stirred for $7 \mathrm{hrs}$. The reaction mixture was dried and purified by preparative thin layer chromatography (chloroform/methanol $=5 / 1,2 \%$ acetic acid) to give $8 b(3.8 \mathrm{mg}, 78 \%)$ as the slightly brown oil of acetic acid salt.

HR-ESI-MS (positive): $[\mathrm{M}+\mathrm{H}]+$ Found $\mathrm{m} / \mathrm{z} 254.1125, \mathrm{C}_{11} \mathrm{H}_{16} \mathrm{O}_{4} \mathrm{~N}^{+}$requires $\mathrm{m} / z$ 254.1141; ${ }^{1} \mathrm{H}-\mathrm{NMR}\left(500 \mathrm{MHz}, \mathrm{CD}_{3} \mathrm{OD}, \mathrm{rt}\right): 7.00(1 \mathrm{H}, \mathrm{d}, J=8.7 \mathrm{~Hz}), 6.32(1 \mathrm{H}, \mathrm{d}, J=8.7 \mathrm{~Hz}), 3.44(2 \mathrm{H}$, t, $J=5.9 \mathrm{~Hz}), 3.36(2 \mathrm{H}, \mathrm{t}, J=5.9 \mathrm{~Hz}), 1.93(3 \mathrm{H}, \mathrm{s}) \mathrm{ppm} ;{ }^{13} \mathrm{C}-\mathrm{NMR}\left(67.5 \mathrm{MHz}, \mathrm{CD}_{3} \mathrm{OD}, \mathrm{rt}\right)$ : 174.2, 173.0, 152.5, 150.8, 123.7, 118.1, 108.1, 107.3, 40.3, 40.1, 22.5 ppm; IR (neat): $3327,3099,2939,1635,1558,1545,1497,1459,1435,1363,1285 \mathrm{~cm}^{-1}$.

\section{Affinity gel 9.}

NHS-activated Sepharose ${ }^{\mathrm{TM}}$ ( $2 \mathrm{~mL}$, GE Healthcare Co.) was filled in a plastic column and washed with $1 \mathrm{mM}$ hydrochloric acid $(25 \mathrm{~mL})$ and then replaced with ligand 2 (28 $\mathrm{mg}$ ) dissolved in $1 \mathrm{~mL}$ of coupling buffer (0.2 $\mathrm{M} \mathrm{NaHCO}_{3}, 0.5 \mathrm{M} \mathrm{NaCl}, \mathrm{pH}$ 8.3). After reacting for 2 hours at room temperature, the column was washed with $6 \mathrm{~mL}$ of coupling buffer and subsequently with $12 \mathrm{~mL}$ of blocking buffer $(0.5 \mathrm{M}$ ethanolamine, $0.5 \mathrm{M} \mathrm{NaCl}$, $\mathrm{pH}$ 8.3). After an hour of blocking reaction, the column was washed with $0.1 \mathrm{M}$ Tris- $\mathrm{HCl}$ buffer ( $\mathrm{pH}$ 8.5) and $0.1 \mathrm{M}$ acetate buffer with $0.5 \mathrm{M} \mathrm{NaCl}(\mathrm{pH} 4.0)$ and then used. The residual 2 and the released NHS in the coupling buffer was quantificated by HPLC to determine the amount of ligand on the gel.

HPLC conditions: Column- Inertsustain C18, $\phi 4.6 \times 250 \mathrm{~mm}$ (GL Science Inc.); eluent$50 \%$ aq. Methanol, $0.1 \%$ formic acid; flow rate- $0.8 \mathrm{~mL} / \mathrm{min}$; detection wave length- 254 $\mathrm{nm}$ (for detection of remaining ligand 2); Column- Inertsustain C18, $\phi 4.6 \times 250 \mathrm{~mm}$ (GL Science Inc.); eluent- 5\% Methanol in $10 \mathrm{mM}$ ammonium acetate buffer (pH5.7); flow rate- $0.8 \mathrm{~mL} / \mathrm{min}$; detection wave length- $254 \mathrm{~nm}$ (for detection of liberated NHS)

\subsection{Preparation of crude enzyme from rat intestinal acetone powder.}

Rat intestinal acetone powder ( $5 \mathrm{~g}$ ) was homogenized in $100 \mathrm{~mL}$ of $0.1 \mathrm{M}$ phosphate buffer $(\mathrm{pH} 7.0$, $5 \mathrm{mM}$ EDTA), centrifuged $(15,000 \mathrm{~g} \times 30 \mathrm{~min})$ and the supernatant was collected. For maltase assay, the supernatant was diluted four times by $0.1 \mathrm{M}$ phosphate buffer ( $\mathrm{pH} 6.3$ ) and used as the crude enzyme. For sucrase assay, the supernatant was directly used as the crude enzyme. Sucrase activity and maltase activity was designated as an activity of sucrose and maltose hydrolyzing activity in the 
crude enzyme.

\subsection{Intestinal $\alpha$-glucosidase activity determination.}

Substrate $(300 \mu \mathrm{L} ; 56 \mathrm{mM}$ sucrose or $3.5 \mathrm{mM}$ maltose in $0.1 \mathrm{M}$ phosphate buffer, $\mathrm{pH} 6.3)$ was pre-incubated at $37^{\circ} \mathrm{C}$ for $5 \mathrm{~min}$. Crude enzyme $(200 \mu \mathrm{L})$ was added and reacted for $20 \mathrm{~min}$ at $37^{\circ} \mathrm{C}$. The reaction was stopped by adding $0.75 \mathrm{~mL}$ of $2 \mathrm{M}$ Tris- $\mathrm{HCl}$ buffer $(\mathrm{pH} \mathrm{7.0)}$ and the amount of liberated glucose was measured by glucose oxidase method using Glucose CII-test Wako (Wako Pure Chem. Co.). One unit was defined as an enzyme that hydrolyzed $1 \mu \mathrm{mol}$ of substrate per minute. Experiments are done in duplicate and repeated at least three times and the representative result is shown in the figures.

\subsection{Intestinal $\alpha$-glucosidase inhibitory activity determination.}

Sample solution dissolved in DMSO $(50 \mu \mathrm{L})$ and substrate $(250 \mu \mathrm{L} ; 56 \mathrm{mM}$ sucrose or $3.5 \mathrm{mM}$ maltose in $0.1 \mathrm{M}$ phosphate buffer, $\mathrm{pH} 6.3$ ) was pre-incubated at $37^{\circ} \mathrm{C}$ for $5 \mathrm{~min}$. Crude enzyme (200 $\mu \mathrm{L}$ ) was added and reacted for $20 \mathrm{~min}$ at $37^{\circ} \mathrm{C}$. The reaction was stopped by adding $0.75 \mathrm{~mL}$ of $2 \mathrm{M}$ Tris- $\mathrm{HCl}$ buffer ( $\mathrm{pH}$ 7.0) and the amount of liberated glucose was measured by glucose oxidase method using Glucose CII-test Wako (Wako Pure Chem. Co.). Experiments are done in duplicate and repeated at least three times and the representative result is shown in the figures. The $\mathrm{K}_{\mathrm{i}}{ }_{\mathrm{i}}$ was calculated from the non-linear regression of Michaelis-Menten equation which was analyzed by Prism 6 (GraphPad Software, Inc.).

\subsection{Affinity purification of maltase by gel 9 .}

Crude enzyme $(1 \mathrm{~mL})$ diluted with $2 \mathrm{~mL}$ of $3.5 \mathrm{mM}$ maltose $(0.1 \mathrm{M}$ phosphate buffer, $5 \mathrm{mM}$ EDTA, pH7.0) was added to the column filled with gel $9(2 \mathrm{~mL})$. The column was washed with $30 \mathrm{~mL}$ of washing buffer (3.5 mM maltose, $0.1 \mathrm{M}$ phosphate buffer, $5 \mathrm{mM}$ EDTA, pH7.0) and then eluted by elution buffer A (0.1 M phosphate buffer, $5 \mathrm{mM}$ EDTA, pH7.0) and elution buffer B (1 M NaCl, 0.1 M phosphate buffer, $5 \mathrm{mM}$ EDTA, pH7.0). Each elution was fractionated, desalted by HiTrap Desalting column (GE Healthcare Co.), concentrated by Amicon Ultra-0.5 Centrifugal Filter Devices (Millipore). Protein concentration of the fractions was quantified by Quick start protein assay (Bio-rad Co.) and the glucosidase activity was measured. For the experiment of Table 1, elution buffer A was skipped.

\subsection{Analysis of purified fraction}

Samples were mixed with $3 \times$ Laemmli buffer and heated at $95^{\circ} \mathrm{C}$ for $5 \mathrm{~min}$. SDS-PAGE was performed with $7.5 \%$ gel and visualized by silver staining. Native-PAGE was performed following the procedure of SDS-PAGE without SDS and denaturing step. The obtained band of Native-PAGE 
gel was cut, extracted and the glucosidase activity was measured. Western blotting was performed by transferring to PVDF membrane (Hybond-P, GE Healthcare Co.). Following antibodies were used: Primary antibody, Maltase-glucoamylase (H-58) (Santa Cruz biotechnology Co.) dilution 1/1000, secondary antibody, anti-rabbit IgG-HRP (Santa Cruz biotechnology Co.) dilution 1/20000. ECL Prime Western blotting detection reagents (GE Healthcare Co.) was used to visualize the protein and was captured with LumiVision PRO 400EX (Aisin seiki Co., Ltd.).

\section{Achnowledgments}

The authors thank Mr. Yusuke Takata and Dr. Eri Fukushi of the GC-MS and NMR Laboratory, Faculty of Agriculture, Hokkaido University, for their skillful measurements of mass spectra.

Supporting material available: Michaelis-Menten equation of $8 \mathrm{~b}$ and NMR spectra of synthetic compounds.

\section{REFERENCES}

1. Hage, D. S.; Anguizola, J. A.; Bi, C.; Li, R.; Matsuda, R.; Papastavros, E.;

Pfaunmiller, E.; Vargas, J.; Zheng, X. J. Pharm. Biomed. Anal. 2012, 69, 93-105.

2. Urh, M.; Simpson, D.; Zhao, K. Methods Enzymol. 2009, 463, 417-38.

3. Terpe, K. Appl. Microbiol. Biotechnol. 2003, 60, 523-33.

4. Zhao, X.; Li, G.; Liang, S. J. Anal. Methods Chem. 2013, 2013, 581093.

5. Block, H.; Maertens, B.; Spriestersbach, A.; Brinker, N.; Kubicek, J.; Fabis, R.;

Labahn, J.; Schäfer, F. Methods Enzymol. 2009, 463, 439-473.

6. Cheung, R. C.; Wong, J. H.; Ng, T. B. Appl. Microbiol. Biotechnol. 2012, 96, 1411-1420.

7. Guan, D.; Chen, Z. Biotechnol. Lett. 2014, 36, 1391-406.

8. Kato, E.; Sasaki, T.; Ueda, M. Bioorg. Med. Chem. 2008, 16, 4600-16. 
9. Lu, M.; Ngo, W.; Mei, Y.; Munshi, V.; Burlein, C.; Loughran, M. H.; Williams, P. D.; Hazuda, D. J.; Miller, M. D.; Grobler, J. A.; Diamond, T. L.; Lai, M. T. Protein Expr. Purif. 2010, 71, 231-9.

10. Ogata, M.; Kameshima, Y.; Hattori, T.; Michishita, K.; Suzuki, T.; Kawagishi, H.; Totani, K.; Hiratake, J.; Usui, T. Carbohydr. Res. 2010, 345, 2623-9.

11. Valsasina, B.; Kalisz, H. M.; Isacchi, A. Expert Rev. Proteomics 2004, 1, 303-15.

12. Wan, Y.; Hur, W.; Cho, C. Y.; Liu, Y.; Adrian, F. J.; Lozach, O.; Bach, S.; Mayer, T.; Fabbro, D.; Meijer, L.; Gray, N. S. Chem. Biol. 2004, 11, 247-59.

13. Gao, H.; Kawabata, J. Bioorg. Med. Chem. Lett. 2008, 18, 812-5.

14. Arsiningtyas, I. S.; Gunawan-Puteri, M. D.; Kato, E.; Kawabata, J. Nat. Prod. Res. 2014, $28,1350-3$.

15. Krentz, A. J.; Bailey, C. J. Drugs 2005, 65, 385-411.

16. Yoshikawa, M.; Murakami, T.; Shimada, H.; Matsuda, H.; Yamahara, J.; Tanabe, G.; Muraoka, O. Tetrahedron Lett. 1997, 38, 8367-8370.

17. Lee, L. M.; Salvatore, A. K.; Flanagan, P. R.; Forstner, G. G. Biochem. J. 1980, 187, $437-46$.

18. Flanagan, P. R.; Forstner, G. G. Biochem. J. 1978, 173, 553-563.

19. Kato, E.; Oikawa, K.; Takahashi, K.; Kawabata, J. Biosci. Biotechnol. Biochem. 2012, $76,1044-6$.

20. Dahlqvist, A.; Telenius, U. Biochem. J. 1969, 111, 139-46.

21. Quezada-Calvillo, R.; Rodriguez-Zuniga, F.; Underdown, B. J. Biochem. Biophys. Res. Commun. 2002, 295, 394-400. 


\section{Supplementary material}

Selective purification of intestinal maltase complex by affinity chromatography employing an uncompetitive inhibitor as the ligand

Eisuke Kato, ${ }^{*}$ Hiroki Tsuji and Jun Kawabata*

Laboratory of Food Biochemistry, Division of Applied Bioscience, Graduate School of Agriculture, Hokkaido University, Kita-ku, Sapporo, Hokkaido 060-8589, Japan

*Corresponding author:

E.Kato eikato@chem.agr.hokudai.ac.jp; J. Kawabata junk@chem.agr.hokudai.ac.jp 


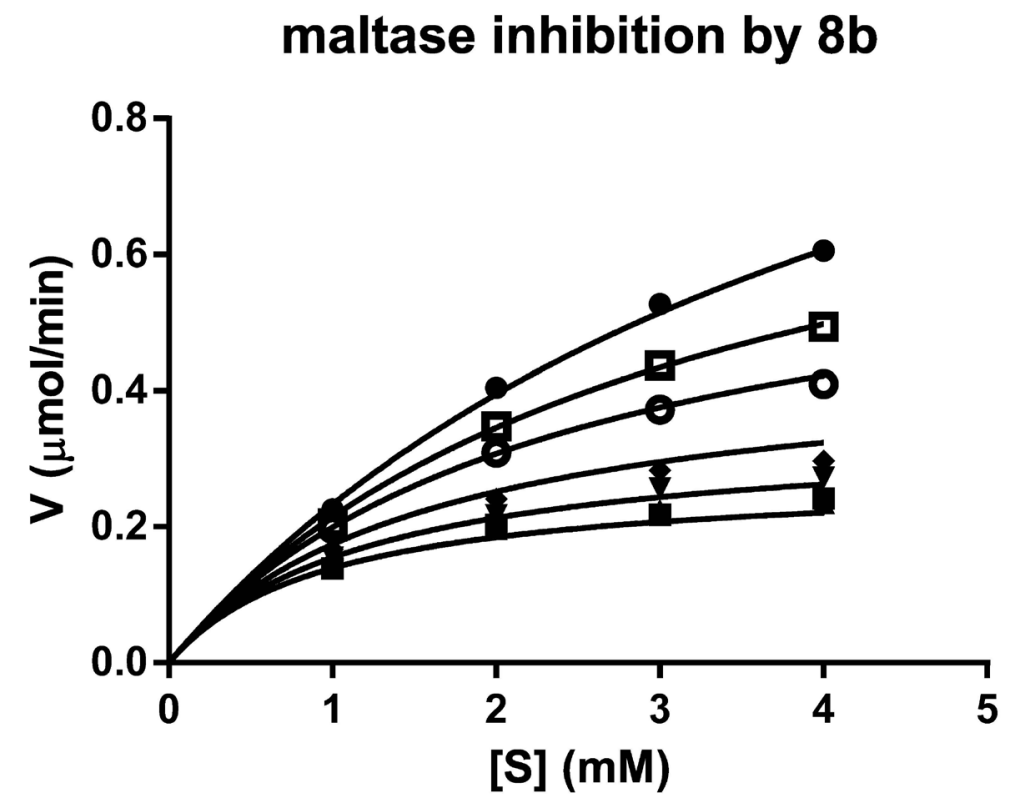

$$
\begin{aligned}
& \rightarrow 0 \\
& -\quad 50 \\
& +\quad 40 \\
& \rightarrow \quad 30 \\
& \rightarrow \quad 20 \\
& -\quad 10 \\
& \mathbf{7} 5
\end{aligned}
$$

sucrase inhibition by $\mathbf{8 b}$

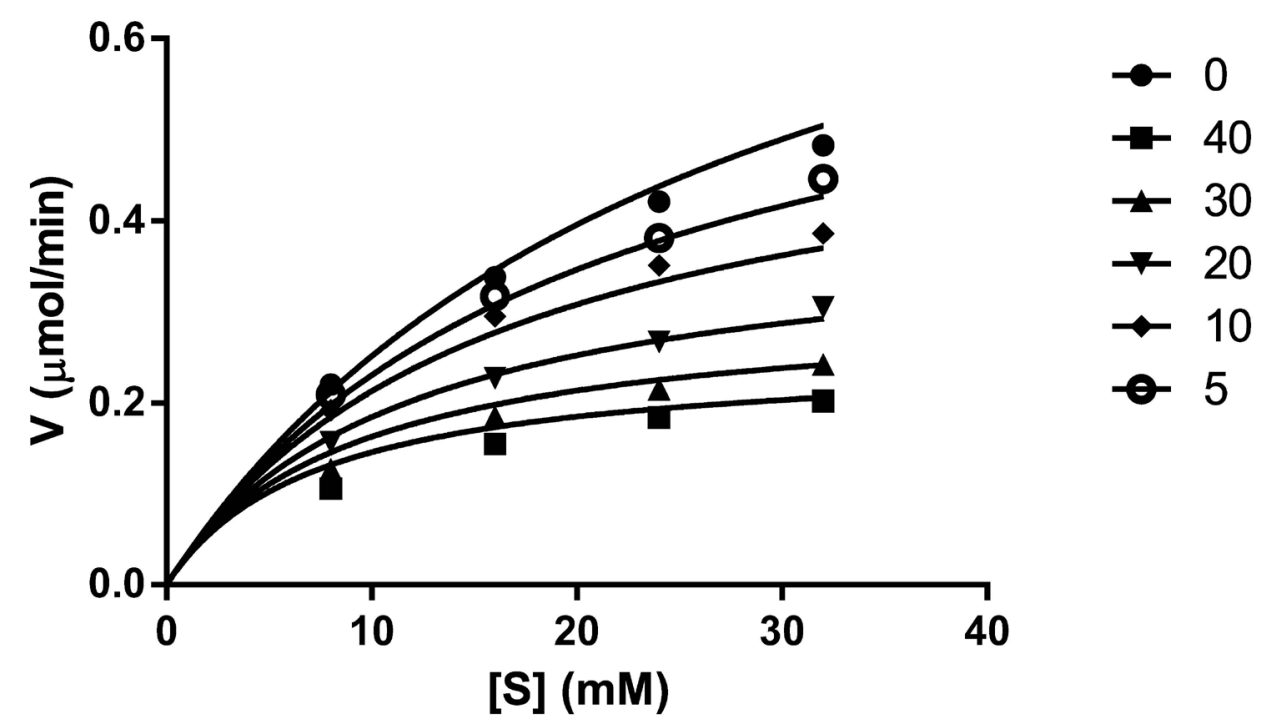

Supplementary Figure 1. Michaelis-Menten equation of $\mathbf{8 b}$. 

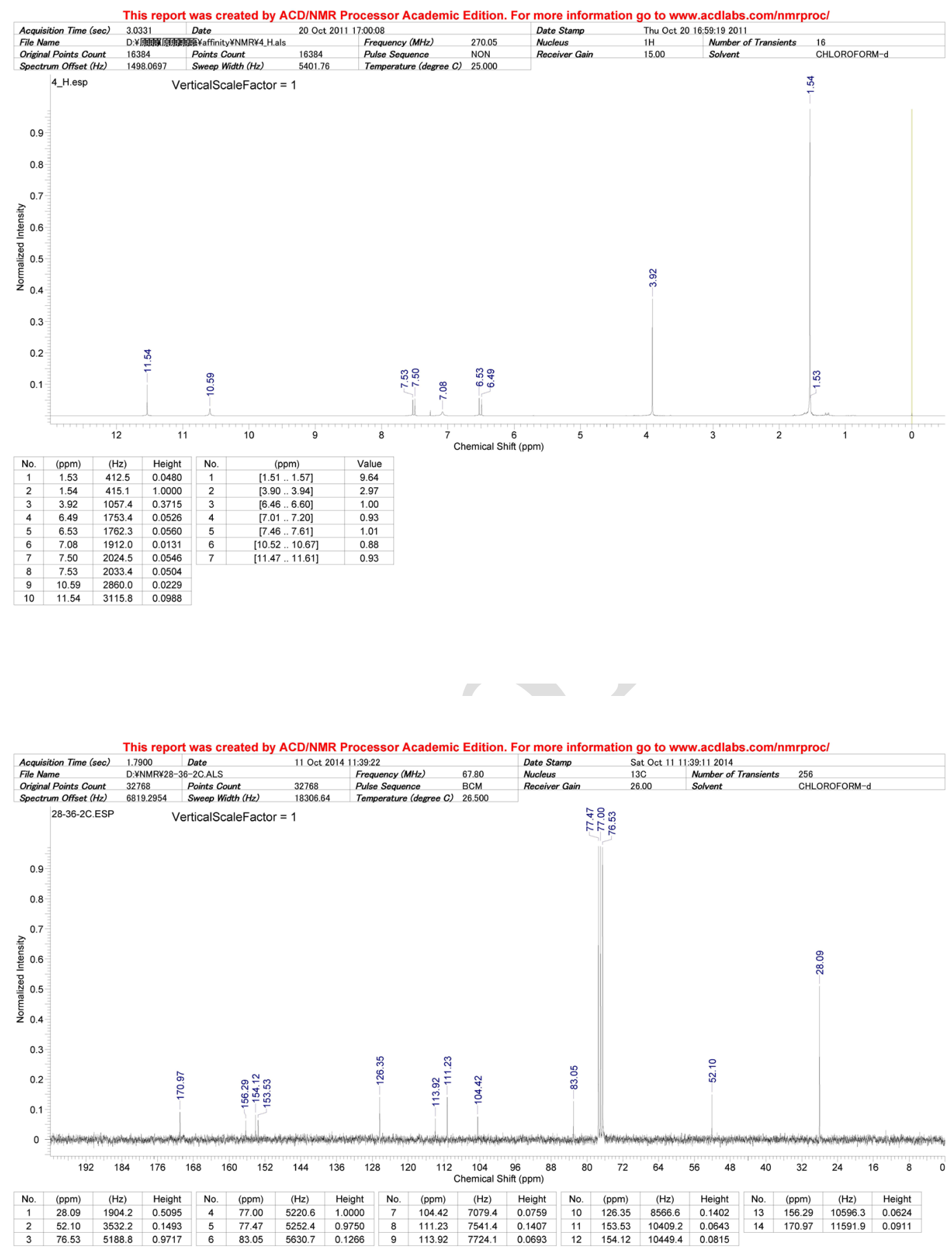

Supplementary Figure $2 .{ }^{1} \mathrm{H}$ and ${ }^{13} \mathrm{C}$ NMR of compound 4. 

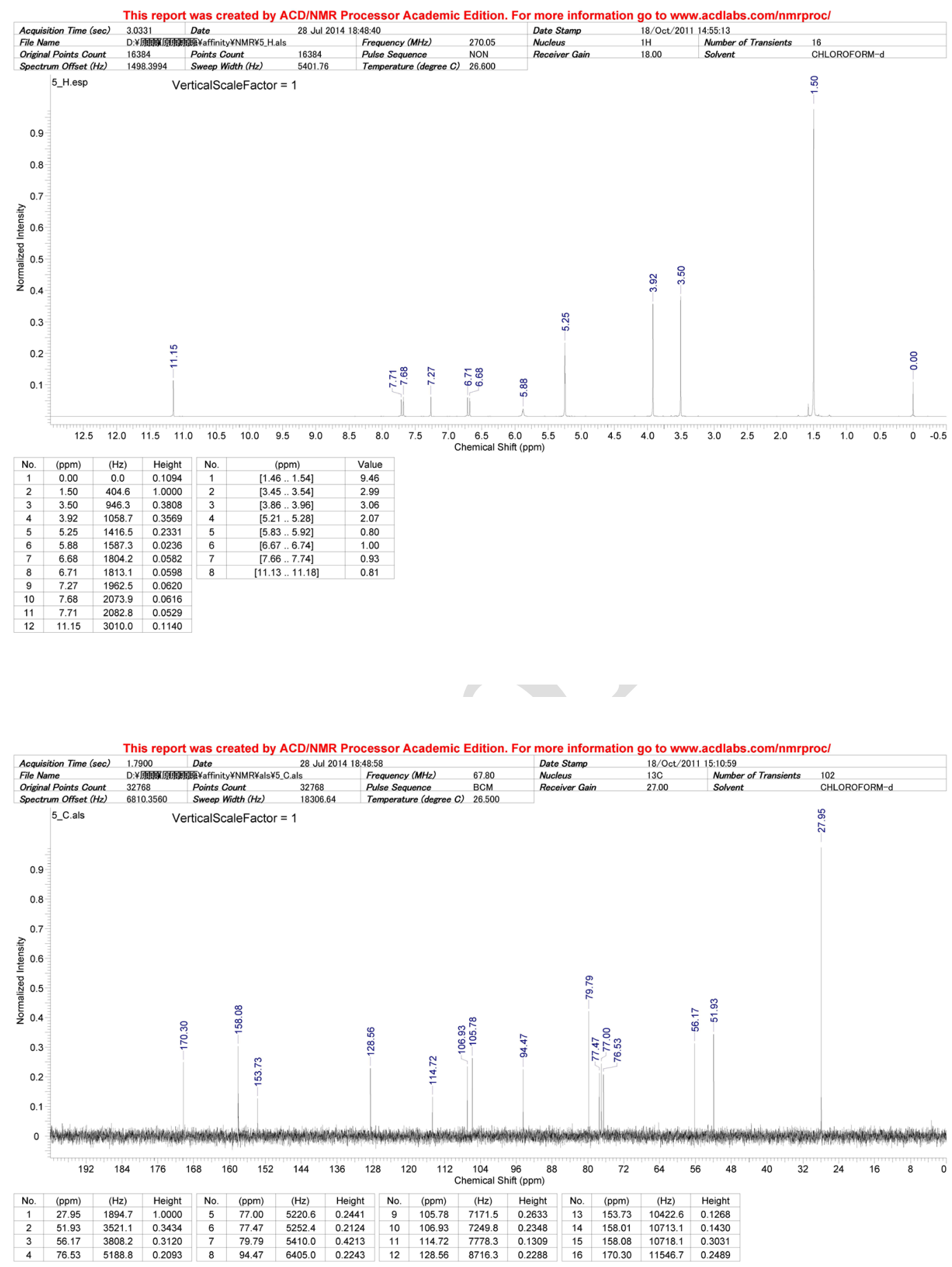

Supplementary Figure $3 .{ }^{1} \mathrm{H}$ and ${ }^{13} \mathrm{C}$ NMR of compound 5 . 

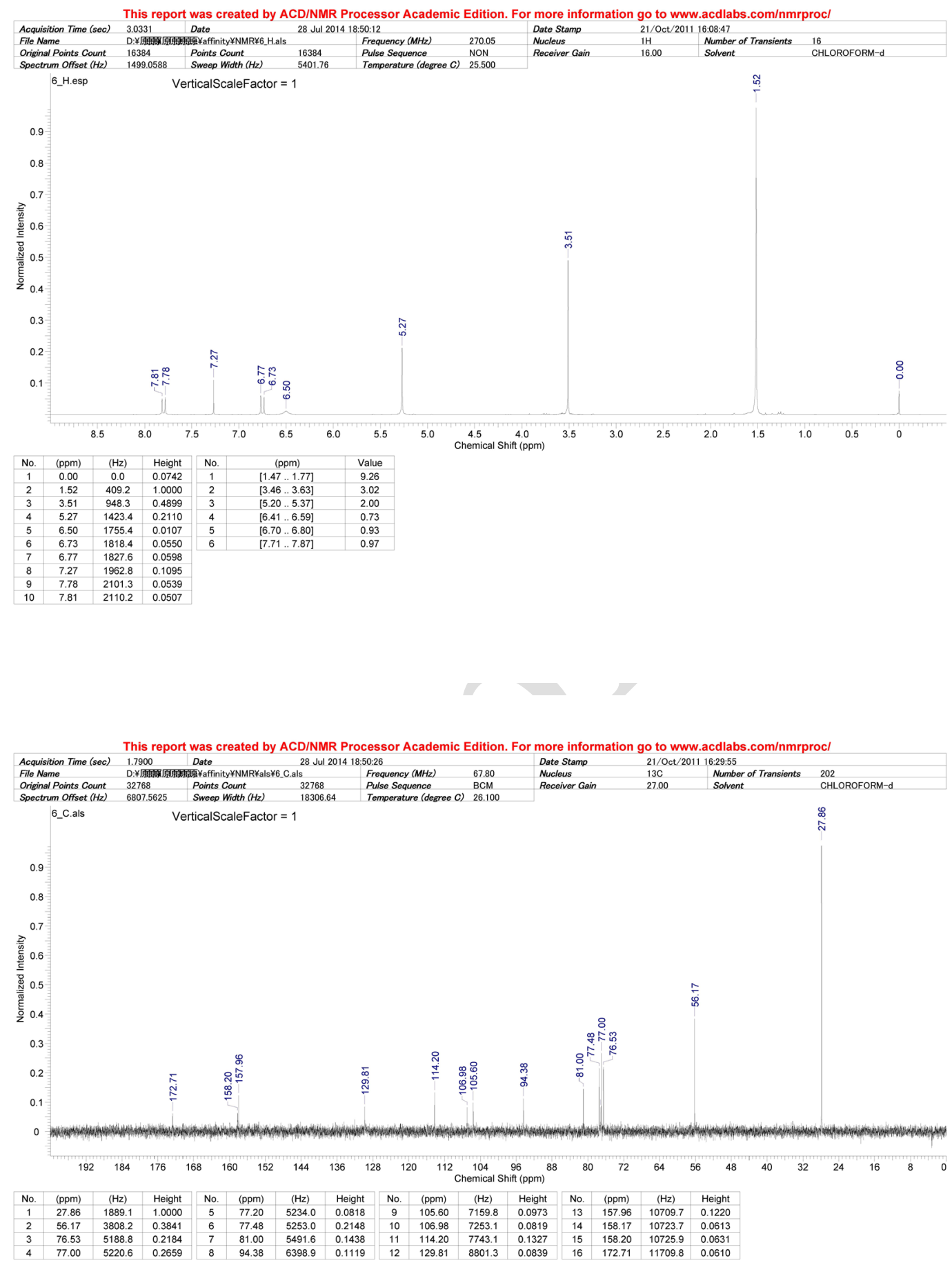

Supplementary Figure $4 .{ }^{1} \mathrm{H}$ and ${ }^{13} \mathrm{C}$ NMR of compound 6. 

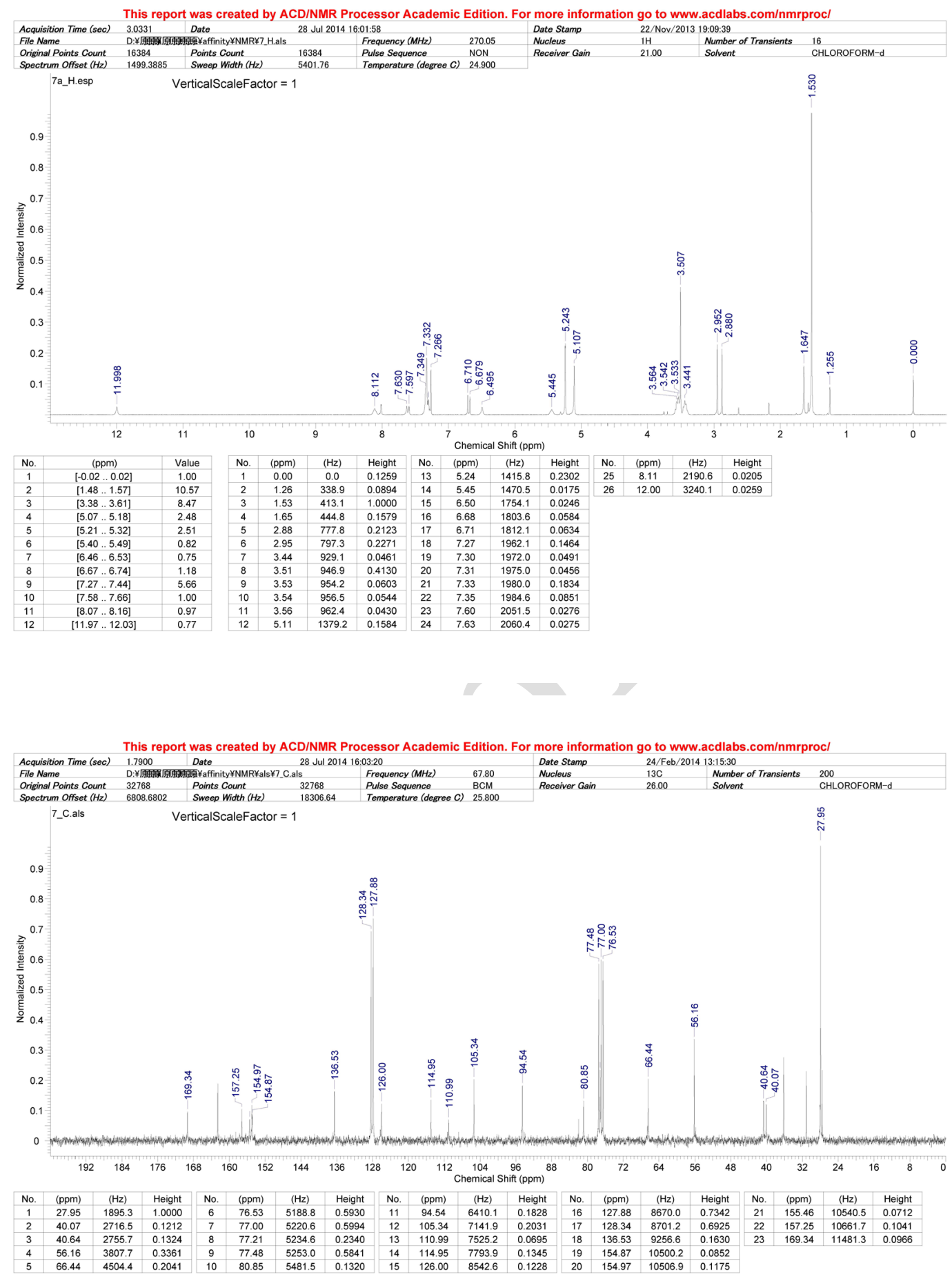

Supplementary Figure 5. ${ }^{1} \mathrm{H}$ and ${ }^{13} \mathrm{C}$ NMR of compound 7a. 

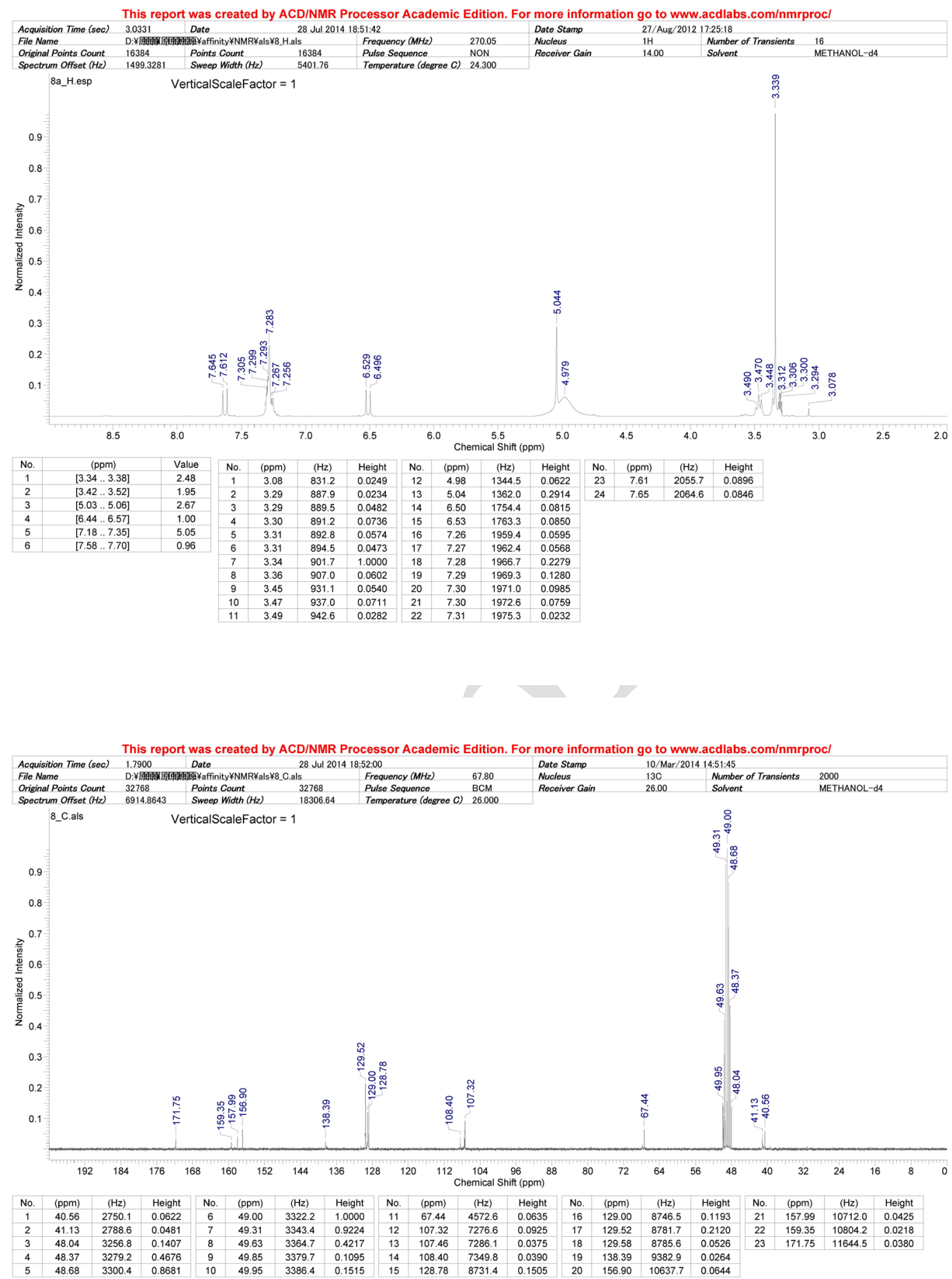

Supplementary Figure 6. ${ }^{1} \mathrm{H}$ and ${ }^{13} \mathrm{C}$ NMR of compound 8a. 

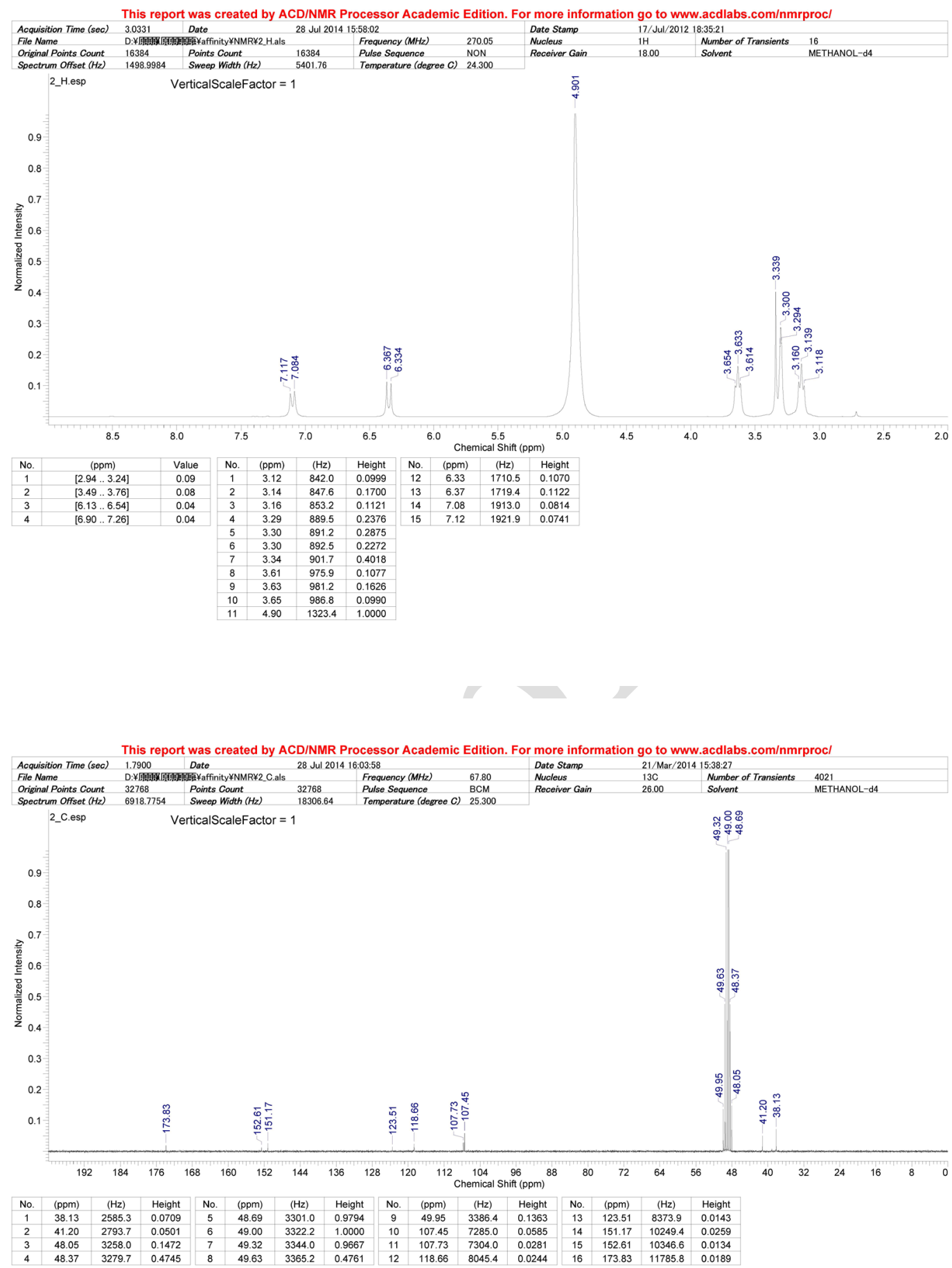

Supplementary Figure 7. ${ }^{1} \mathrm{H}$ and ${ }^{13} \mathrm{C}$ NMR of compound 2. 

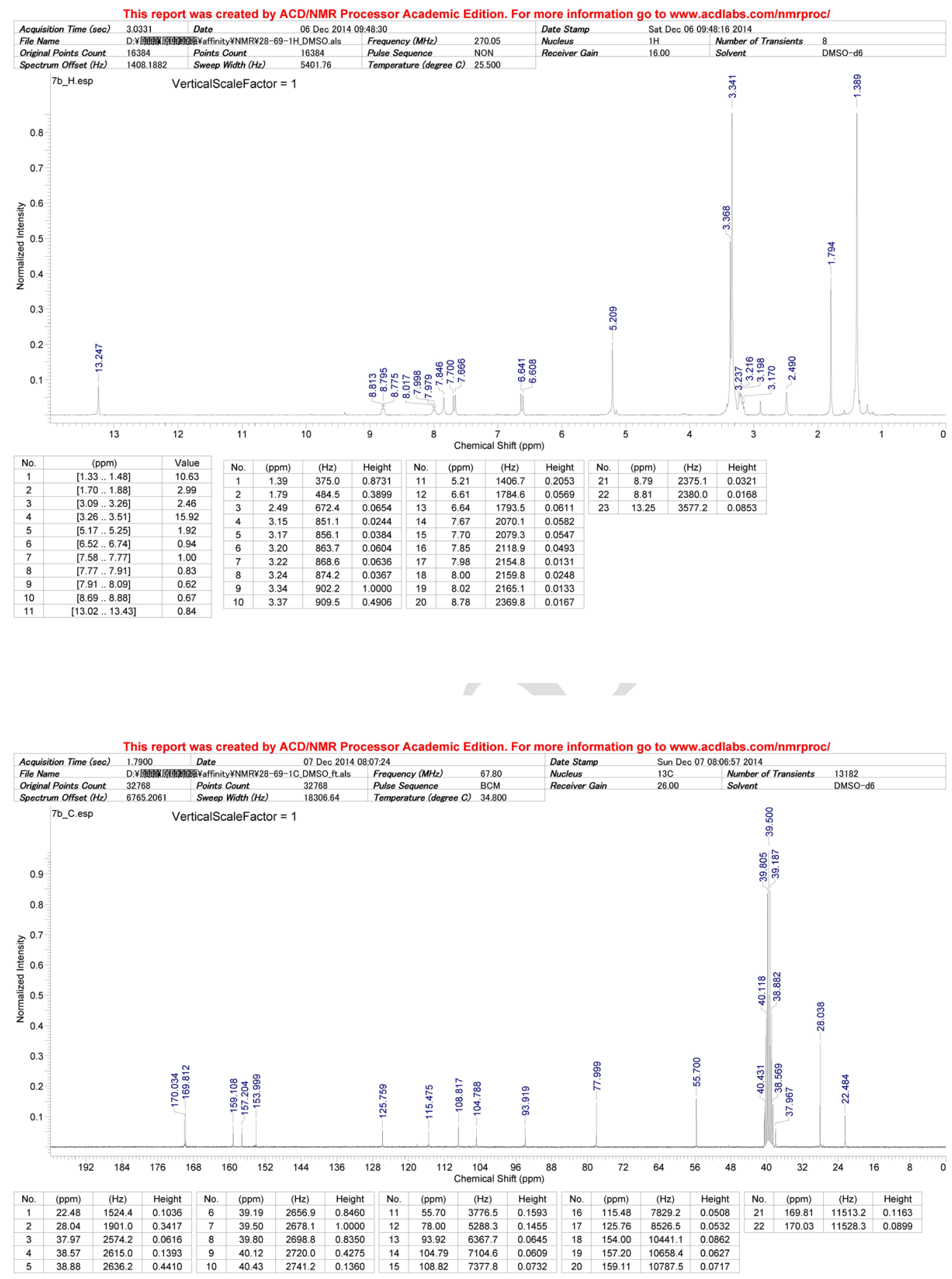

Supplementary Figure 8. ${ }^{1} \mathrm{H}$ and ${ }^{13} \mathrm{C}$ NMR of compound $7 \mathrm{~b}$. 

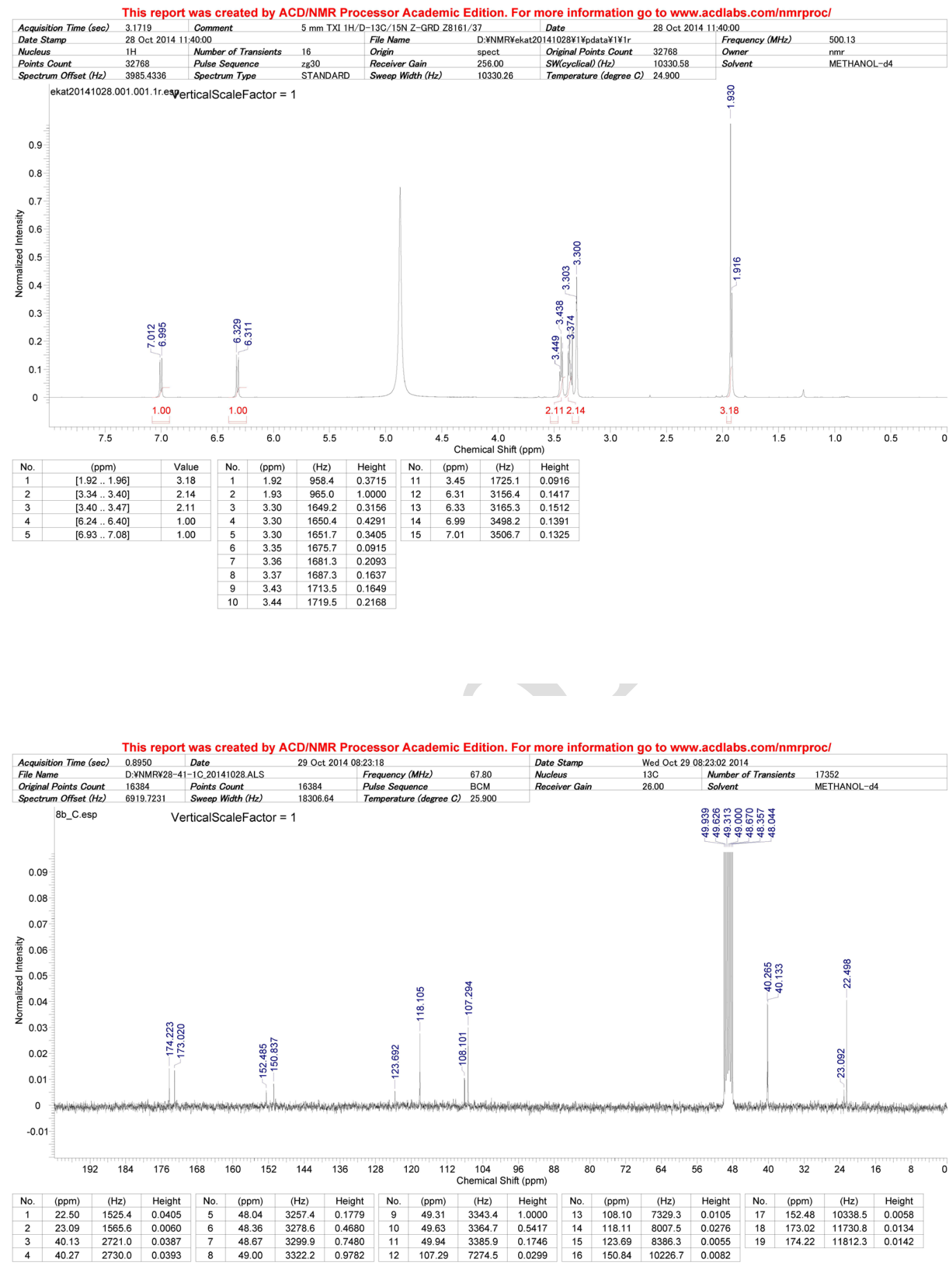

Supplementary Figure 9. ${ }^{1} \mathrm{H}$ and ${ }^{13} \mathrm{C}$ NMR NMR of compound $8 \mathbf{b}$. 